http://dx.doi.org/10.4314/jae.v17i1.8

\title{
Building the capacity of agricultural extension personnel for effective implementation of agricultural transformation agenda in Nigeria
}

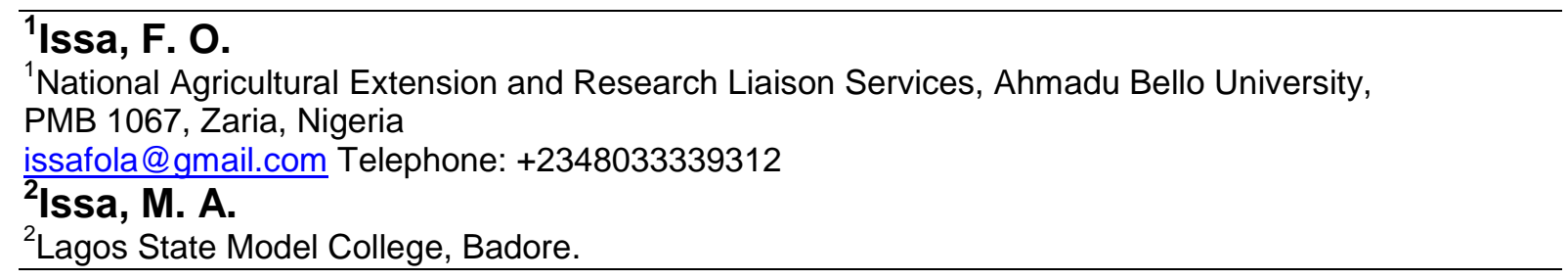

\begin{abstract}
This paper reviews the capacity (number, quality and motivation) of the extension personnel in Nigeria; and describes farmers' perception of the quality of extension service delivery using evidences from literature, reports of organizations as well as experiences from field research. Findings reveal a tremendous shortage in the number and quality of extension personnel across the country as major reason for the poor performance of the ADPs thereby leaving no hope for the "beautiful" transformation agenda. This paper strongly recommends immediate recruitment of new hands as well as full implementation of a well-designed capacity building programme so as to ensure a sustainable extension service delivery system where extension personnel can operate in the expected commercial (agriculture-driven) economy.
\end{abstract}

Keywords: Capacity building, training, extension personnel, sustainability, Agricultural transformation Agenda (ATA)

\section{Introduction}

Capacity building is the ability of people, organization and society as a whole to manage their affairs to achieve set goals. The existence of capacity is indicated by the functional presence of one or the combination of the following: viable institutions and related organization; commitment and vision of leadership, financial and material resources; and skilled human resources. In agricultural extension, capacity building is the process whereby relevant stakeholders and organizations unleach, strengthen, create, adapt and maintain capacity over time, usually with the objective of assuring sustainable agricultural growth and improving the lives of the stakeholders (Eremie, 2006). It requires the acquisition of individual skills as well as development of opportunities to put the skills to productive use (Issa et al., 2010). The task of transforming agriculture from the shackle of peasantry to a modern one (as embedded in the Agricultural Extension Transformation Agenda (AETA) under the overall Agricultural Transformation Agenda (ATA) requires extension personnel with good mental and physical ability to give the maximum output. Extension personnel must be skilled in the following: technical subject-matter area, extension service administration and operation, human resource development, programme development process, pedagogical skills, communication strategies, and evaluation techniques (Issa, 2010). This will ensure a high level of professional competence in the discharge of official functions as may be demanded of him/her.

The roles of various stakeholders in the ATA should be clearly spelt out. The 2001 Agricultural Policy was perhaps the first to address the issues of public agricultural 
extension service in Nigeria with particular reference to, the roles and responsibilities of the various tiers of government and the private. The new policy thrust was premised on the fact that "self-sufficiency in food production (as embedded in the 1988 Policy) was too limited in scope. Policy objective must transcend selfsufficiency to cover food security" (FMARD, 2002). In order to achieve the objective of food security, the 2001 agricultural policy assigned roles and responsibilities to the different tiers of government and the private sector. However, the participation of the private sector in agricultural research and extension has remained low and the most sited excuse has been "the inconsistencies and somersaults" in government policies.

Although agricultural extension is on the concurrent list of the constitution, the federal government to-date, has always taken the responsibility for a major portion of the funding, policy formulation and direction, while the States' Agricultural Development Projects (ADPs), are the primary agencies responsible for public extension delivery at the grassroots nationwide. The quality of staff and the resources of the Local Government Authorities (LGAs) are such that their participation in agricultural extension delivery has only been very minimal, as against the provisions. Even with this policy in place, none of the three tiers of government has had the commitment and the will power to implement the tenets of the document with respect to the financing and provision of an effective and efficient agricultural extension service in Nigeria. Worse still, most of the local governments chairmen are neither aware of the document nor its provisions. (Arokoyo, 2009).

Against this background, this paper reviews the capacity (number, quality and motivation) of the extension personnel in Nigeria; and assesses their training needs using evidences from literature, reports of organizations as well as experiences from field research.

\section{The Nigeria Agricultural Transformation Agenda (ATA)}

Nigeria investment in agriculture is exceptionally low averaging approximately $2 \%$ of government expenditure. This is exemplified by poor ranking in agricultural indices e.g. mechanization intensity of 10 tractors per 100 ha of land (Indonesia is 241 tractors per $100 \mathrm{ha}$ ); irrigation of $0.8 \%$ of arable land (Thailand has irrigated $28 \%$ of arable land). Nigeria is the World largest importer of US wheat to the tune of N635b per annum; the second largest importer of rice N356billion per annum. Sugar and fish importation remains N217 and N97 billion per annum. Food importation grows at $11 \%$ per annum. Unfortunately, the imported items are those that can be produced in abundance in the country. This ugly situation prompted the formulation of ATA to revitalize the agricultural sector.

The ultimate goal was to create an industrialized, high growth, diversified economy, creating jobs and wealth as well as providing security for the people. This is intended to be achieved through i) import substitution agricultural development; ii) exportoriented agricultural sector; iii) growing value-added agro-processing sector; and iv) backward integration into higher value added manufacturing. Provision of correct policy, regulations and efficient administrative framework also remained a major objective. Under the arrangement, the Government intended to i) focus on agriculture as a business and not as development project; ii) focus on value chain for commodities where Nigeria has comparative and competitive advantage; iii) develop strategic partnership (with State Government, local Government, related ministries, 
private sector, farmers groups and civil society) to stimulate investment to drive the market-led agricultural transformation; and iv) focus sharply on youth and women (FMARD, 2011). The commodities being promoted under the value chain approach include cassava, rice, cocoa, soybean, sorghum, maize, oil-palm, cotton, livestock, fisheries and horticulture.

To effectively drive the ATA, an Agricultural Extension Transformation Agenda (AETA) was articulated with the following objectives:

i) To establish a Federal Department of Agricultural Extension (FDAE) which will oversee, monitor and provide the leadership needed for an efficient and effective agricultural extension and advisory service delivery in Nigeria.

ii) To review the agricultural extension policies within the subsisting agricultural policies and recommend appropriate policies that will ensure the effective participation of all stakeholders in a stable policy environment and adequate funding for the delivery efficient and effective agricultural extension and advisory services.

iii) To recommend appropriate institutional structures and arrangements for the delivery of effective and efficient multi-plural agricultural extension and advisory services in Nigeria, using the value chain approach.

iv) To recommend demand-responsive extension systems/approaches and tools that will ensure the delivery of efficient and effective agricultural extension and advisory services for all the multi-actors in the targeted commodity value chains of interest to government.

It is expected that the FDAE will remain focused and committed to the stated objectives bearing in mind the political circumstances of the country.

\section{Agricultural Extension Personnel (AEP)}

Agricultural extension personnel include all professional staff working in the extension organization. Importantly, the staff of extension component of the ADPs i.e. Director of extension, zonal extension officers (ZEOs), block extension supervisors (BESs), block extension agent for Women in Agriculture (BEA/WIA), and village extension agents (VEAs). Other categories of extension personnel include those who work directly with the Ministry of Agriculture including the newly created Federal Department of Agricultural Extension (FDAE). Others are found in the research institutes across the country. Possession of basic professional training in agricultural extension at a degree level remains the hub. However, OND and HND holders abound in the ADPs across the country. For effective job performance, the number and qualification of such personnel must not be compromised.

\section{Training Needs and Expected Capacity Building}

Using the value chain approach requires a more knowledge and skills-based, demand-responsive extension and advisory services which make capacity building an absolutely important requirement which will be addressed using a public-privatepartnership approach (PPP) with appropriate incentives. Capacity building will cover the following groups: unemployed youths and graduates, all categories of field extension staff including agricultural quarantine; farmers, producers and processors, 


\section{Journal of Agricultural Extension}

Vol. 17 (1) June, 2013

ISSN 1119-944X

and all other actors on the targeted value chains and the private advisory service providers. Continuous direct link with training institutions remains very vital for the success of any capacity building effort. A clear and definitive career path must be created for extension personnel in the nation's ADPs. The staff of the new Federal Department of Extension should be trained to effectively posit them for the future responsibilities of the Department. Experience professionals should be mopped from relevant agencies to hold the Department very strongly. It is expected that professionalism will be a major consideration for the staffers of the new Department. NAERLS and NPAFS (2011) reported 31 areas of training needs across the ADPs. Data gathering skills, crop improvement and pests and diseases management, preand post-season training other refresher trainings as well as use of computer were the most prominent areas of training needs (Table 1). 
Table 1

Training Needs of ADPs in Nigeria

\begin{tabular}{|c|c|c|c|}
\hline Subject Matter of Training & $\begin{array}{l}\text { No. of } \\
\text { Requesting }\end{array}$ & ADPs & Percentage \\
\hline Accounting management & 1 & & 0.9 \\
\hline $\begin{array}{l}\text { Agricultural extension and communication } \\
\text { methods }\end{array}$ & 6 & & 5.4 \\
\hline Agricultural policy analysis & 1 & & 0.9 \\
\hline $\begin{array}{l}\text { Agricultural products storage and } \\
\text { preservation }\end{array}$ & 3 & & 2.7 \\
\hline Agricultural Projects Monitoring \& Evaluation & 3 & & 2.7 \\
\hline $\begin{array}{l}\text { Agricultural projects planning and } \\
\text { management }\end{array}$ & 9 & & 8.1 \\
\hline Artificial insemination in cattle & 1 & & 0.9 \\
\hline Audio-visual Media Production & 2 & & 1.8 \\
\hline $\begin{array}{l}\text { Community Demand-driven Development } \\
\text { approach }\end{array}$ & 2 & & 1.8 \\
\hline Conflict resolution \& management skills & 1 & & 0.9 \\
\hline $\begin{array}{l}\text { Crop improvement and pests/diseases } \\
\text { management }\end{array}$ & 12 & & 10.8 \\
\hline Farm Radio \& TV programmes production & 1 & & 0.9 \\
\hline $\begin{array}{l}\text { Farmer Field Schools (FFS) extension } \\
\text { approach }\end{array}$ & 2 & & 1.8 \\
\hline Fisheries culture, nutrition and breeding & 5 & & 4.5 \\
\hline Food processing & 1 & & 0.9 \\
\hline Full-time academic training courses & 1 & & 0.9 \\
\hline $\begin{array}{l}\text { Human resource management and office } \\
\text { administration }\end{array}$ & 5 & & 4.5 \\
\hline Livestock extension methods & 2 & & 1.8 \\
\hline Livestock pests \& diseases management & 1 & & 0.9 \\
\hline Livestock production and nutrition & 2 & & 1.8 \\
\hline $\begin{array}{l}\text { Management of agricultural extension } \\
\text { services }\end{array}$ & 2 & & 1.8 \\
\hline Market linkages & 1 & & 0.9 \\
\hline Meteorological training & 1 & & 0.9 \\
\hline On-farm soil erosion control & 1 & & 0.9 \\
\hline $\begin{array}{l}\text { Participatory Agricultural Extension (PAE) } \\
\text { approach }\end{array}$ & 1 & & 0.9 \\
\hline Participatory Rural Appraisal (PRA) & 1 & & 0.9 \\
\hline Participatory training techniques & 6 & & 5.4 \\
\hline $\begin{array}{l}\text { Pre-season, post-season \& other refresher } \\
\text { trainings }\end{array}$ & 13 & & 11.7 \\
\hline Records and information management & 3 & & 2.7 \\
\hline $\begin{array}{l}\text { Survey methods and statistical analysis } \\
\text { packages }\end{array}$ & 8 & & 7.2 \\
\hline Use of Computer, Web and other ICTs in & 13 & & 11.7 \\
\hline Total & & & 99.9 \\
\hline
\end{tabular}

Source: NAERLS and NPAFS (2011) 
Current Status of Extension Personnel in Nigeria: Number, quality, motivation Very high Extension Agent (EA): Farm family ratio as well as poor staffing and nonreplacement of retired staff had been long identified as the major problem plaguing extension service thereby rendering the country's ADPs inactive. In 2012, the number of extension agents reduced in many States owing to retirements, mortality and movement of staff to other jobs (NAERLS, 2012).

Extension commonly has staffing problems. In most cases, extension organizations have posts that are either vacant or filled by under-qualified personnel (Contado, 1997). Table 2 shows that most ADPs are grossly understaffed. NAERLS and NPAFS (2011) reported that extension staff are poorly exposed to relevant trainings due to funding inadequacy. This has resulted in increased EA: Farm family ratio in all the States. Given the mission, scope of the work, and available resources, the ADPs are in dire need of not just full complement of frontline extension agents but qualified and well trained ones in order for the system to function properly in capacitizing the rural actors in a bid to transform the country's agriculture. 


\section{Table 2}

Adequacy and Quality of Staff in ADP (2008 - 2011)

\begin{tabular}{|c|c|c|c|c|c|}
\hline \multirow[t]{2}{*}{ Zone } & \multirow[t]{2}{*}{ State } & \multicolumn{4}{|c|}{ Adequacy and Quality of Staffing } \\
\hline & & 2008 & 2009 & 2010 & 2011 \\
\hline \multirow[t]{7}{*}{ NCZ } & BENUE & NA & Inadequate & Fair & Inadequate \\
\hline & FCT & Adequate & Adequate & Inadequate & Fair \\
\hline & KOGI & Adequate & Adequate & Adequate & Inadequate \\
\hline & KWARA & Inadequate & Inadequate & Inadequate & Very inadequate \\
\hline & NASSARAWA & NA & Adequate & Adequate & Inadequate \\
\hline & NIGER & Adequate & Adequate & Fair & Fair \\
\hline & PLATEAU & NA & Fair & Fair & Inadequate \\
\hline \multirow[t]{6}{*}{ NEZ } & ADAMAWA & Fair & Inadequate & Fair & Inadequate \\
\hline & BAUCHI & Fair & Adequate & Fair & Fair \\
\hline & BORNU & Inadequate & Adequate & Adequate & Inadequate \\
\hline & GOMBE & Fair & Adequate & Fair & Fair \\
\hline & TARABA & NA & Inadequate & Fair & Inadequate \\
\hline & YOBE & Fair & Inadequate & Fair & Fair \\
\hline \multirow[t]{7}{*}{ NWZ } & JIGAWA & Fair & Fair & Fair & Inadequate \\
\hline & KADUNA & Fair & Fair & Fair & Fair \\
\hline & KANO & Fair & $\begin{array}{l}\text { Very } \\
\text { Inadequate }\end{array}$ & Fair & Fair \\
\hline & KATSINA & Inadequate & Inadequate & NA & NA \\
\hline & KEBBI & Fair & Fair & Fair & Fair \\
\hline & SOKOTO & $\begin{array}{l}\text { Very } \\
\text { inadequate }\end{array}$ & Inadequate & Weak & Very inadequate \\
\hline & ZAMFARA & $\begin{array}{l}\text { Very } \\
\text { inadequate }\end{array}$ & Fair & Fair & Fair \\
\hline \multirow[t]{5}{*}{ SEZ } & $\mathrm{ABIA}$ & Inadequate & Adequate & Fair & Inadequate \\
\hline & ANAMBRA & Inadequate & Fair & Fair & Very Inadequate \\
\hline & EBONYI & NA & Inadequate & Fair & Inadequate \\
\hline & ENUGU & NA & Inadequate & Inadequate & Very Inadequate \\
\hline & IMO & $\begin{array}{l}\text { Very } \\
\text { Inadequate }\end{array}$ & Inadequate & Fair & Inadequate \\
\hline \multirow[t]{6}{*}{ SSZ } & AKWA-IBOM & NA & Inadequate & Fair & Inadequate \\
\hline & BAYELSA & NA & Inadequate & Inadequate & Very inadequate \\
\hline & $\begin{array}{l}\text { CROSS- } \\
\text { RIVERS }\end{array}$ & NA & Fair & Fair & Inadequate \\
\hline & DELTA & NA & Fair & Fair & Fair \\
\hline & EDO & NA & Inadequate & Inadequate & Inadequate \\
\hline & RIVERS & NA & Inadequate & Fair & Very Inadequate \\
\hline \multirow[t]{6}{*}{ SWZ } & EKITI & NA & Inadequate & Fair & Inadequate \\
\hline & LAGOS & Inadequate & Adequate & Inadequate & Very inadequate \\
\hline & OGUN & Inadequate & Adequate & Fair & Weak \\
\hline & ONDO & Inadequate & Inadequate & Fair & Fair \\
\hline & OSUN & NA & Adequate & Fair & Inadequate \\
\hline & OYO & NA & Adequate & Fair & Inadequate \\
\hline
\end{tabular}

Source: NAERLS and NPAFS National report of agricultural performance survey of wet season in Nigeria 
Farm families: The high number of farm families across the country underscores the need for more village extension agents (VEAs) if farmers must be covered effectively. Kano State had the highest number of farm families of 840,095 followed by Akwa Ibom State with 685,095 farm families (NAERLS and NPAFS, 2010).

EA:Farmer ratio: The UN standard for EA: Farmer ratio remained 1:500 - 800. This ratio is the ideal for ease of coverage by VEAs. Unfortunately, the realization of this ratio has being a wild goose chase. Bauchi, Yobe and Ebonyi States had the highest number of VEAs of 306, 265 and 257 respectively (NAERLS). However, only Ebonyi recorded an increase of $65 \%$ over the 2010 record. The EA:Farm family ratio record was highest in Bayelsa (1:10,568); Anambra $(1: 9,409)$; and Cross-Rivers $(1: 4,729)$. In each of the States, the large ratio was worsened by the low number of frontline EAs on board. This trend of dwindling number of VEAs had persisted over the years (Table 2) as most ADPs could not recruit new VEAs even with the dire needs.

Number of Subject Matter Specialists (SMSs): The SMSs (who are the immediate teacher of extension agents) are the main link between the research institutes and the ADPs. Proven and relevant technologies from research are taught by the SMSs to the VEAs. Feedback to research as a way of evaluating progress is also achieved through the SMSs during the FNTs and MTRMs. Hence, the availability of SMSs in different agricultural enterprise - crop, livestock, fisheries, agro-processing and women-in-agriculture - remains a major performance indicator in the ADP system. NAERLS and NPAFS (2011) reported that Taraba State had only 1 SMS, Yobe State had only 7 SMSs. Generally, there is low number of SMSs across the country. This implies that technology transfer is inefficient.

Number of Block Extension Supervisors (BESs): The role of BESs is very crucial in extension especially under the Training and Visit system. The BESs are the frontline supervisory agent. The number of BES should depend on the number of VEAs with a standard of 1:8 BES:VEA ratio. Ebonyi State has an average of 1:11 BES:VEA ratio. Most States ADPs have low BES:VEA ratio. This should be an advantage to supervision all things being equal.

Number of BEA(WIA): Extension contact to women (which is a major avenue where women can be empowered in order to meet their challenges) is bedeviled by lack and inadequacy of BEA(WIA) in most ADPs. NAERLS and NPAFS (2011) reported that Jigawa, Kano, Osun, Cross-Rivers and Bayelsa States did not have BEA(WIA) while Edo State had only 1. Zamfara State had the lowest (56) record of extension visit to farmers according to NAERLS and NPAFS (2011). This indicates that technology transfer is unrealistic.

In order to improve the staffing situation in ADPs, an innovative Federal government intervention is required.

\section{Quality of Extension Service as Perceived by Farmers}

Figure 1 indicates the rating of the quality of extension services as perceived by farmers across the agro-ecological Zones. It indicates a general score of between "fair" and "just good". This gives the impression that farmers do not derive total satisfaction from the extension system as it is currently operated and do expect better extension delivery services (Ikani et al., 2010). 


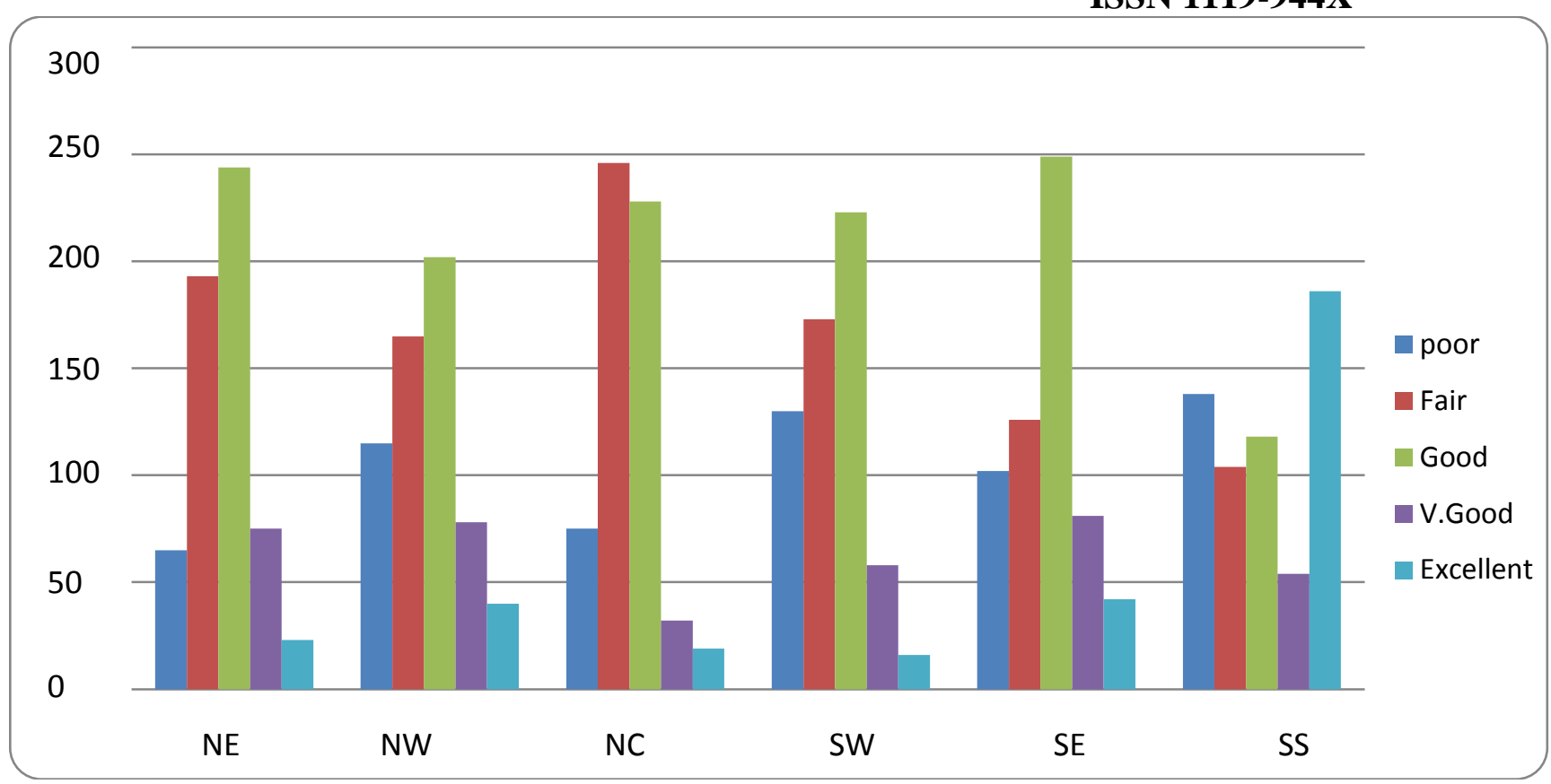

Figure 1: Comparison of the rating of the quality of extension services by farmers across the six geopolitical zones of Nigeria.

\section{Way Forward:}

\section{Professionalization of extension practice}

A cursory look at the nation's ADPs reveals that there are Programme Managers (PMs) and Directors of extension (including other practitioners) who do not have background in agriculture. A situation where extension work has been reduced to 'everybody's' work (thereby making mockery of the underlying principles of extension) is not too tidy. There is need for extension policy to regulate its practice. This can be achieved by creating a professional institute of agricultural extension (IAE). A long-term human development programme should be instituted in order to ensure dynamism within the extension organizations.

\section{Review of Curriculum at Various Levels for Extension Education}

Curriculum is about subjects taught at an educational institution, or the topics taught within a subject. Presently, products from our agricultural institutions are poorly equipped. For practical engagement in modern agricultural operation, the curriculum should not place emphasis on theories and paper qualifications only. To produce next generation farmers who will transform our agricultural development the followings are recommended:

$\checkmark$ The National Board for Technical Education (NBTE) should overhaul the current colleges of agriculture curriculum to lay more emphasis on practical and skill acquisitions during pre-service and in-service trainings at the diploma levels.

$\checkmark$ Industrial attachments of students of agriculture for a minimum of six months in the course of their training to well establish farms should be mandatory.

$\checkmark$ The newly established FDAE should be fully engaged in the standardization and accreditation of curriculum operated in the agricultural tertiary institutions.

$\checkmark$ Agricultural science should be made compulsory in secondary schools to catch the interest of the youth young in modern farming principle. 
$\checkmark$ Modern agricultural entrepreneurship should be made a core course in all the departments of agriculture, to help produce self-employable market oriented farmers.

$\checkmark$ Evidence of real skill acquisition should bases for offer of certificates on graduation and employment.

\section{Review of Allowances of Extension Workers}

Extension staff is at 3 tiers of government and they should be provided for appropriately as follows:

1. At the federal level, they should be provided with motor vehicles and allowances to enable them supervise and monitor the activities;

2. At the State level, vehicles should be provided and allowances for the field activities;

3. At the Local government level where the bulk of extension agents should be either BESs, BEAs and EAs, motor cycles should be provided to them on loan and appropriate allowances given for the maintenance.

4. Other field services allowances should be paid to all categories of staff depending on the rank and activities.

5. Hazard allowances would be paid because of the risk involve in extension work.

\section{Conclusion and Recommendations}

This paper strongly recommends immediate recruitment of new hands as well as full implementation of a well-designed capacity building programme so as to ensure a sustainable extension service delivery system where extension personnel can operate in the expected commercial (agricultural-driven) economy as enshrined in the ATA.

\section{References}

Arokoyo, J.O. (2009). An Effective and Functional Extension Service to Maximize Farmers Productivity. An Invited Paper Presented at the National Conference on Agricultural Finance and the Role of Communication in Sustainable Development in Nigeria, Organized by PR Value Consulting, Murtala Muhamad Library Complex, Kano, Sept. $29^{\text {th }}-30^{\text {th }}$.

(2003). ICTs in the Transformation of Agricultural Extension: The Case of Nigeria, Paper presented at the $6^{\text {th }}$ Consultative Expert Meeting of CTA's Observatory on ICTs, Wageningen, Sept. $23^{\text {rd }}-25^{\text {th }}$.

(1998). "Agricultural Technology Development and Dissemination: A Case Study of Ghana and Nigeria Experiences" Published by: The Technical Center for Agriculture and Rural Cooperation (CTA). (ACP-EU), The Netherlands, 55pp.

Contado, T. E. (1997). Formulating Extension Policy, In Swanson, B. E., Bobert, P. B. and Andrew, J. S. (eds) Improving Agricultural Extension: A Reference Manual, FAO, Rome, pp. 107 - 114.

Eremie, S. (2006). Capacity building in agricultural extension: The World Bank experience in Nigeria. Journal of Agricultural Extension, Vol 9, pp 1 - 7.

Federal Ministry of Agriculture and Rural Development (FMARD) (2011). Presidential Brief on Agricultural Transformation Agenda, Presented $9^{\text {th }}$ September, pp. 92. 


\section{Journal of Agricultural Extension}

Vol. 17 (1) June, 2013

ISSN 1119-944X

FAMARD (2002). "Agriculture in Nigeria: Policy (Before and Now) Analysis of the Existing (1988) Agricultural Policy and the Revised Policy" Federal Ministry of Agriculture and Rural development, Abuja.

FAMARD (2001). "Federal Republic of Nigeria: New Agricultural Policy Thrust" Federal Ministry of Agriculture and Rural Development, Abuja.

FAMARD (1988). Federal Republic of Nigeria: Agricultural Policy, Federal Ministry of Agriculture and Rural Development, Lagos.

Federal Government of Nigeria (FGN) (2009). Nigeria: Vision 20:2020. The First National Implementation for NV20:2020 (2010 - 2013). Volume 1: The Vision and Development Priorities (The Economic Transformation Blueprint), National Planning Commission, Abuja.

FGN (2008). "National Food Security Program" Federal ministry of Agriculture and Water Resources, Abuja, Nigeria.

Ikani E.I., Tologbonse, E.B., Arokoyo, J.O. Issa, F.O. and Abdullahi, Y.M. (2010). The State of Agricultural Development Projects (ADPs) in Nigeria. International Journal of Agricultural and Rural Development (IJARD), 1 (2), pp $229-241$.

Issa, F.O. (2010). Agricultural extension administration and operations (AEM 412). Samaru College of Agriculture, Division of Agricultural Colleges, Ahmadu Bello University, Zaria.

Issa, F.O., Auta, S.J. \& Jaji, M.F.O. (2010). An overview of the challenges of agricultural extension practice, Capacity building and sustainability. International Journal of Agricultural and Rural Development (IJARD), 1 (2), pp $51-58$.

Madukwe, M.C. (2008). Practice without Policy: The Nigerian Agricultural Extension Service, An Inaugural Lecture of the University of Nigeria, Nsukka delivered on April 29 $9^{\text {th }}$. UNN Press, pp.76.

National Agricultural Extension and Research Liaison Services (NAERLS) and National Food Reserve Agency (NFRA) (2009). National report of Agricultural performance survey of 2009 wet season in Nigeria. December. 128 pp. (2008). National report of Agricultural performance survey of 2008 wet season in Nigeria. December. 95 pp.

National Agricultural Extension and Research Liaison Services (NAERLS) and National Programme on Agriculture and Food Security (NPAFS) (2011). National report of Agricultural performance survey of 2011 wet season in Nigeria. December. 175 pp.

(2010). National report of Agricultural performance survey of 2010 wet season in Nigeria. December. 182 pp.

National Agricultural Extension and Research Liaison Services (NAERLS) (2012). Executive summary of Agricultural performance survey of 2012 wet season in Nigeria. October, 15 pp.

Omotayo, A.M. (2010). The Nigerian farmer and the elusive crown. $30^{\text {th }}$ Inaugural Lecture of the University of Agriculture, Abeokuta, Nigeria. Pp 52. 